\title{
PEMANFAATAN SUMBER DAYA UDANG PENAEID DI TELUK CILETUH, PALABUHANRATU BERDASARKAN ANALISIS KESESUAIAN KAWASAN
}

\section{THE UTILIZATION OF PENAEID SHRIMP RESOURCES IN CILETUH BAY, PALABUHANRATU BASED ON AREA SUITABILITY ANALYSIS}

\author{
Sugeng Hartono ${ }^{1 *}$, Etty Riani ${ }^{2}$, Fredinan Yulianda $^{2}$, \& Gondo Puspito ${ }^{3}$ \\ ${ }^{1}$ Program Studi Pengelolaan Sumberdaya Pesisir dan Lautan, IPB, Bogor, 16680, Indonesia \\ ${ }^{2}$ Departemen Manajemen Sumberdaya Perairan, FPIK-IPB, Bogor, 16680, Indonesia \\ ${ }^{3}$ Departemen Pemanfaatan Sumberdaya Perikanan, FPIK-IPB, Bogor, 16680, Indonesia \\ *E-mail: sugeng_hartono@apps.ipb.ac.id
}

\begin{abstract}
The utilization of penaeid shrimp resources in Ciletuh Bay, Sukabumi Regency is at high risk for overexploitation, since the area distribution of its penaeid shrimp is relatively narrow. Zoning-based management need to be implemented as an effort to manage its resources and to explain the function and width of an area for the utilization activities. The research aim to design an appropriate and measurable area of utilization based on the potency and its habitat characteristics spatially. Field and laboratory studies were conducted to collect and analyse the samples of catch and sediment. All activities conducted between February and April 2019. Purposive sampling methods used for sampling. The operation of trawl and Van Veen Grab were carried out to collect catch sample and sediment sample respectively. Spatial analysis was conducted on geographic information system (GIS) software to produce a utilization area by using inverse distance weighted (IDW) analysis and map algebra. The results showed two species of penaeid shrimp caught in its waters, namely dogol shrimp (Metapenaeus ensis) and jerbung shrimp (Fenneropenaeus merguiensis). Based on its habitat characteristics, the sediments of its waters categorized as silt. The waters categorized as most suitable (S1) was 209.254 ha or $43.7 \%$ of the total of the study area (479.288 ha). While the waters categorized as suitable (S2) was $209.067 \mathrm{ha} \mathrm{(43.6 \% )}$ and unsuitable (N) $60.967 \mathrm{ha} \mathrm{(12.7 \% ).}$
\end{abstract}

Keywords: Ciletuh, habitat suitability, Palabuhanratu, penaeid shrimp, sediment

\begin{abstract}
ABSTRAK
Pemanfaatan sumberdaya udang penaeid di Teluk Ciletuh, Kabupaten Sukabumi berisiko tinggi untuk tereksploitasi secara berlebih karena daerah penyebaran udang penaeid relatif sempit di perairannya. Pengelolaan berbasis zonasi perlu diterapkan sebagai upaya pengelolaan sumber daya maupun upaya untuk menjelaskan fungsi dan luas satu kawasan pemanfaatan. Penelitian bertujuan untuk merancang satu kawasan pemanfaatan sumber daya udang penaeid yang sesuai dan terukur berdasarkan potensi dan karakteristik habitatnya secara spasial. Penelitian lapang dan laboratorium dilakukan untuk mengumpulkan dan menganalisis sampel hasil tangkapan dan sedimen. Seluruh kegiatannya berlangsung antara Februari-April 2019. Metode pengumpulan sampel yang digunakan adalah purposive sampling. Pengoperasian pukat tarik dan Van Veen Grab dilakukan untuk mengumpulkan masing-masing sampel hasil tangkapan dan sampel sedimen. Analisis spasial dilakukan dengan perangkat lunak sistem informasi geografis (SIG) untuk menghasilkan satu kawasan pemanfaatan dengan menggunakan analisis inverse distance weighted (IDW) dan map algebra. Hasil penelitian menunjukkan bahwa terdapat dua jenis udang penaeid yang tertangkap di perairannya, yaitu udang dogol (Metapenaeus ensis) dan udang jerbung (Fenneropenaeus merguiensis). Berdasarkan karakteristik habitatnya, sedimen permukaan dasar perairannya dikategorikan sebagai lanau (silt). Perairan yang dikategorikan sangat sesuai (S1) seluas 209,254 ha atau 43,7\% dari total luas kawasan kajian (479,288 ha). Perairan yang dikategorikan sesuai (S2) seluas 209,067 ha (43,6\%) dan yang tidak sesuai (N) 60,967 ha $(12,7 \%)$.
\end{abstract}

Kata kunci: Ciletuh, kesesuaian habitat, Palabuhanratu, sedimen, udang penaeid 


\section{PENDAHULUAN}

Udang penaeid merupakan kelompok organisme bentik yang terdistribusi secara dominan di perairan tropis, terutama di perairan pantai negara-negara yang berada di lintang rendah (Dall et al., 1990; Hart et al., 2018). Perairannya ditandai dengan temperatur berkisar antara $20-23^{\circ} \mathrm{C}$. Jumlah dan jenisnya semakin sedikit, ketika temperatur perairannya semakin rendah dan lintang tinggi.

Perairan Indonesia dikategorikan sebagai perairan tropis yang masuk ke dalam kawasan perairan Indo-Pasifik (Spalding et al., 2007). Lokasi perairannya membuat distribusi udang penaeid tersebar luas di perairan pantainya dengan kelimpahan yang tinggi. Dall et al. (1990) menyebutkan kurang lebih 125 spesies yang tersebar di kawasan perairan Indo-Pasifik.

Sumber daya udang penaeid di Indonesia biasanya dimanfaatkan untuk kegiatan perikanan tangkap. Beberapa jenis udang penaeid yang tertangkap adalah udang dogol ( $M$. ensis), udang jerbung ( $F$. merguiensis), udang jinga ( $M$. affinis), dan udang tiger (Penaeus semisulcatus) (FAO, 1998; Mehanna et al., 2012; Hufiadi, 2008; Loneragan et al., 1994). Semua jenis udang tersebut dijumpai di lingkungan bentik dari garis pantai sampai perairan dengan kedalaman kurang atau lebih dari $50 \mathrm{~m}$ (Marini et al., 2017).

Satu kawasan perairan dengan pemanfaatan sumber daya udang yang aktif dapat dijumpai di Teluk Ciletuh, Kabupaten Sukabumi. Perairannya termasuk ke dalam perairan Teluk Palabuhanratu dan WPPNRI 573. Hasil tangkapannya tergolong cukup banyak. Berdasarkan data Dinas Kelautan dan Perikanan (Dislutkan) Kabupaten Sukabumi, produksi udang di Teluk Palabuhanratu mencapai $10.204 \mathrm{~kg}$ pada 2017. Nilai produksinya mencapai Rp502.895.000,00 di tahun yang sama.

Pemanfaatan sumber daya udang di

Teluk Ciletuh dibatasi oleh luas daerah penangkapan ikan (DPI) yang kecil. Balai Penelitian Perikanan Laut (2014) menyatakan daerah penyebaran udang penaeid di WPPNRI 573 relatif sempit, karena sebagian besar perairannya bukan habitat yang disukai udang penaeid. Habitat yang disukainya adalah perairan dengan kedalaman kurang dari $40 \mathrm{~m}$ dan berada di sekitar muara sungai serta yang masih dipengaruhi oleh hutan mangrove. Jumlah sumber daya perikanannya berisiko tinggi untuk tereksploitasi secara berlebih. Kepmen KP Nomor 50 Tahun 2017 juga telah menetapkan bahwa tingkat pemanfaatan sumber daya udang penaeid WPPNRI 573 telah berstatus overexploited.

Nelayan menggunakan beberapa jenis alat tangkap untuk menangkap udang, yaitu pukat dogol, jaring klitik, dan jaring tiga lapis. Pengoperasiannya dilakukan di lokasi penangkapan yang penentuannya cenderung sembarang dan subjektif. Peraturan Daerah Provinsi Jawa Barat Nomor 5 Tahun 2019 tentang RZWP3K Provinsi Jawa Barat Tahun 2019-2039 menyatakan bahwa perairan Teluk Ciletuh termasuk ke dalam zona perikanan berkelanjutan. Namun demikian, zonasi kawasannya masih untuk kegiatan perikanan secara umum, sehingga penetapannya perlu dilakukan secara lebih detail.

Kegiatan pemanfaatan sumber daya udang penaeid di Teluk Ciletuh harus dikelola secara bijak agar kegiatannya berkelanjutan. Menurut Yulianda (2019) sumber daya pesisir dan laut sangat rentan terhadap kegiatan manusia dan pemanfaatannya perlu dikelola secara tepat. Salah satu upaya pengelolaan yang dapat diterapkan adalah berbasis zonasi, yang mana mampu menjelaskan fungsi dan luas satu kawasan. Penerapannya dapat memudahkan masyarakat dan pengelola dalam mengeksploitasi sumber daya sesuai dengan potensinya.

Kajian pengelolaan berbasis zonasi merujuk pada analisis kesesuaian karakteristik habitat sumber daya. Hasilnya dijadikan sebagai dasar dalam menentukan 
satu kawasan pemanfaatan yang sesuai untuk kegiatan perikanan tangkap (Marasabessy et al., 2018). Karakteristik habitat udang ditentukan berdasarkan karakteristik sedimen permukaan dasar perairan, karena udang dewasa menghabiskan sebagian besar hidupnya di permukaan dasar perairan. Menurut Dall et al. (1990), distribusi udang dewasa sangat berkaitan dengan karakteristik sedimen yang ada di satu perairan. Setiap spesies udang memiliki preferensi tersendiri terhadap sedimen yang cocok sebagai habitat dan sumber makanannya, namun informasi spasial untuk kegiatan pemanfaatannya masih sangat minim. Oleh karenanya, penelitian perlu dilakukan untuk merancang satu kawasan pemanfaatan sumber daya udang penaeid yang sesuai dan terukur berdasarkan karakteristik habitatnya.

\section{METODE PENELITIAN}

\subsection{Waktu dan Tempat Penelitian}

Penelitian dibagi ke dalam dua kegiatan, yaitu penelitian lapang dan laboratorium. Penelitian lapang meliputi pengumpulan sampel hasil tangkapan perikanan udang dan sampel sedimen. Seluruh kegiatannya berlangsung antara Februari-April 2019. Lokasi yang dipilih adalah perairan Teluk Ciletuh, Palabuhanratu, Kabupaten Sukabumi, Jawa Barat. Perairannya menjadi muara bagi dua sungai, yaitu Sungai Cimarinjung dan Sungai Ciletuh. Kedua sungai berkontribusi aktif dalam pembentukan daerah penangkapan udang, sebab transportasi sedimennya membawa sumber makanan yang mendukung kelangsungan hidup organisme di lingkungan bentik (Nittrouer et al., 2007; Gray \& Elliot, 2009; Goineau et al., 2011). Dengan demikian, perairannya berpotensi untuk dijadikan sebagai daerah penangkapan udang.

Kegiatan pengambilan sampel dilakukan di 23 titik sampling (Figure 1). Penelitian laboratorium berupa analisis karakteristik sedimen yang dilakukan di Laboratorium Produktivitas dan Lingkungan Perairan (Proling), Departemen Manajemen Sumber Daya Perairan, Fakultas Perikanan dan Ilmu Kelautan, Institut Pertanian Bogor.

\subsection{Alat dan Bahan}

Alat yang digunakan dalam penelitian lapang terdiri atas satu unit perahu, satu unit pukat tarik (pukat dogol), kamera, alat tulis, measuring board, GPS, timbangan digital, dan Van Veen Grab. Adapun bahan penelitian adalah hasil tangkapan berupa udang dan sedimen.

\subsection{Pengambilan Data}

Pengambilan sampel dilakukan pada penelitian lapang dengan metode purposive sampling. Tujuannya untuk mengumpulkan sampel hasil tangkapan dan sedimen berdasarkan area yang telah ditentukan (Bolliger et al., 2007). Sampel sedimen dikumpulkan dengan Van Veen Grab sebelum pengangkatan pukat tarik ke atas perahu pada setiap operasi penangkapan ikan (Blomqvist, 1991).

Jenis data yang dihasilkan dari penelitian lapang hanya data primer yang terdiri atas data berat, jenis, dan jumlah setiap hasil tangkapan. Selain itu, data tiga fraksi sedimen dihasilkan dari analisis karakteristik sedimen dengan metode pengayakan di laboratorium (Brower \& Zar, 1998; Eleftheriou, 2013). Data sekunder juga dikumpulkan untuk melakukan kajian lanjutan terhadap karakteristik habitat udang penaeid. Jenis datanya meliputi data gelombang, arus, pasang surut, suhu, dan salinitas.

\subsection{Analisis Data}

\subsubsection{Pendugaan Biomassa Udang}

Pendugaan biomassa hasil tangkapan di kawasan kajian ditujukan untuk melihat potensi hasil tangkapan di satu luasan perairan (Swaleh et al., 2015). Rumus yang digunakan untuk menghitungnya adalah 


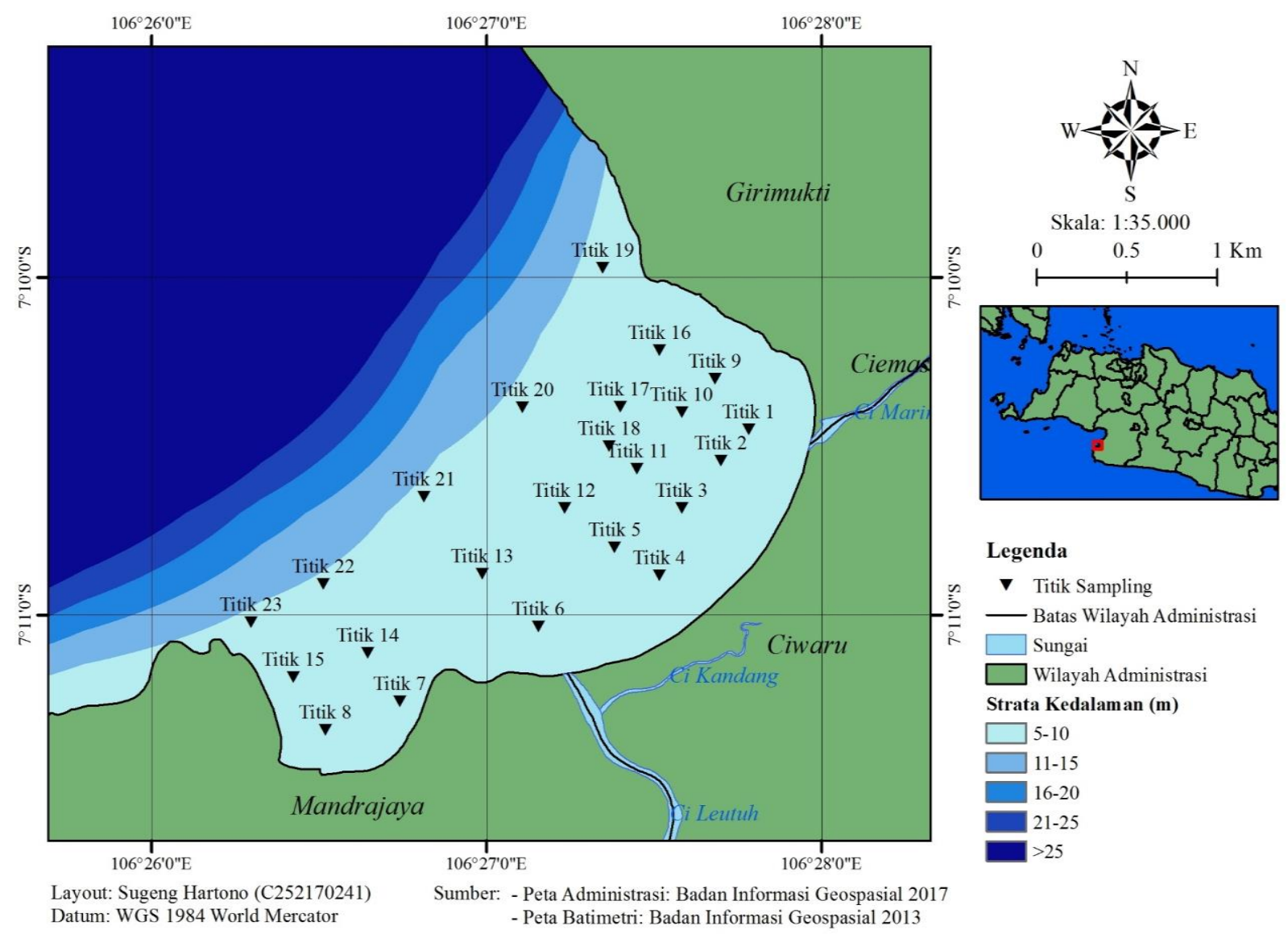

Figure 1. Research location and sampling sites.

sebagai berikut:

$B=\frac{\left(\overline{\left.C w_{2} / a_{2}\right)}\right.}{x_{1}} \times A$

Keterangan: $B=$ dugaan biomassa total; $C w_{i}$ $=$ berat hasil tangkapan di titik sampling $i ; a_{i}$ $=$ luas area sapuan di titik sampling $i ; A=$ total luas kawasan kajian; $X_{1}=$ koefisien $(0,5)$ (Sparre \& Venema, 1998); dan $i=1,2,3, \ldots, n$.

\subsubsection{Analisis Spasial}

Hasil analisis hasil tangkapan, kepadatan, dan karakteristik habitat udang dianalisis secara spasial. Tujuannya untuk menentukan kawasan pemanfaatan yang sesuai untuk perikanan udang. Seluruh data diolah menggunakan perangkat lunak GIS (Price, 2016).
Proses analisis spasial melalui beberapa tahapan utama. Pertama, data spasial beberapa parameter dianalisis untuk menghasilkan raster awal. Analisis komputasi GIS yang digunakan adalah interpolasi yang disebut inverse distance weighted (IDW) (Achilleos, 2011). Persamaan analisis IDW adalah:

$V_{x}=\frac{\sum_{i=1}^{n} \frac{V_{i}}{d_{i}^{n}}}{\sum_{i=1}^{n}\left[\frac{1}{d_{i}^{n}}\right]}$

Keterangan: $V_{x}=$ nilai yang tidak diketahui pada titik koordinat $x ; \quad V_{i}=$ nilai yang diketahui pada titik koordinat $i$; dan $d_{i}=$ jarak antara titik koordinat $x$ dan $i$.

Kedua, seluruh hasil analisis parameter diolah lebih lanjut dengan membuat model (geoprocessing model) ber- 
Table 1. Range of suitability classes and weight from each parameter.

\begin{tabular}{|c|c|c|c|c|c|c|}
\hline \multirow{2}{*}{ Aspect } & \multirow{2}{*}{ Parameter } & \multirow{2}{*}{ Unit } & \multirow{2}{*}{$\begin{array}{c}\text { Weight } \\
(\%)\end{array}$} & \multicolumn{3}{|c|}{ Class conformity interval } \\
\hline & & & & $\mathrm{S} 1$ & $\mathrm{~S} 2$ & $\mathrm{~N}$ \\
\hline \multirow[t]{2}{*}{$\begin{array}{l}\text { Shrimp } \\
\text { resources }\end{array}$} & $\begin{array}{l}\text { Weight of } \\
\text { catch/sweep }\end{array}$ & $\mathrm{kg} /$ sweep & 50 & $0.41-0.6$ & $0.21-0.4$ & $0-0.2$ \\
\hline & Density & $\mathrm{kg} / \mathrm{ha}$ & 25 & $1.6-2.25$ & $0.75-1.5$ & $<0.75$ \\
\hline Habitat & Sand & $\%$ & 15 & $0-1$ & $1.1-2$ & $2.1-4$ \\
\hline \multirow[t]{2}{*}{ characteristic } & Silt & $\%$ & 5 & $>80$ & $70-80$ & $<70$ \\
\hline & Clay & $\%$ & 5 & $0-10$ & $11-20$ & $>20$ \\
\hline Total & & & 100 & & & \\
\hline
\end{tabular}

dasarkan kombinasi biner dan bobot. Modelnya digunakan untuk menentukan kawasan pada masing-masing parameter berdasarkan selang kelas kesesuaian yang terdiri atas "Sangat Sesuai" atau disimbolkan dengan S1, "Sesuai" (S2), dan "Tidak Sesuai" (N). Setiap selang kelas kesesuaian memiliki skor yang berkisar antara 1-3. S1 bernilai 3, S2 (2), dan N (1) (Price, 2016). Adapun nilai bobot masing-masing parameter ditentukan berdasarkan kajian ilmiah dalam penentuan kesesuaian habitat yang prioritas. Nilai bobot ditampilkan dalam bentuk persentase yang nilai totalnya tidak lebih dari $100 \%$. Nilai skor diolah secara komputasi dengan analisis reklasifikasi (reclassify) untuk mengubah nilai pada raster dari analisis IDW. Nilai bobot diolah dengan analisis map algebra untuk menghasilkan satu raster akhir.

Rincian selang kelas dan bobot pada analisis kesesuaian disajikan pada Table 1 . Rinciannya disusun berdasarkan pertimbangan ilmiah dan analisis statistik inferensia, seperti analisis korelasi sesuai Mendenhall et al. (2013). Store \& Jokimäki (2003), Guisan \& Thuiller (2005), serta Morris \& Ball (2006) menyatakan bahwa penentuan selang kelas dan bobot parameter pada analisis kesesuaian dapat ditentukan berdasarkan pertimbangan ilmiah, analisis statistik, dan akademisi.

Penentuan selang kelas dan bobot aspek sumber daya udang mengikuti karakteristik kegiatan perikanan di lokasi penelitian. Selang kelas "sangat sesuai" diasumsikan bernilai sangat menguntungkan untuk kegiatan perikanan, "sesuai" bernilai menguntungkan, dan "tidak sesuai" bernilai tidak menguntungkan (Price, 2016). Parameter hasil tangkapan per sapuan pukat tarik memiliki bobot paling tinggi, karena perannya menunjukkan distribusi sumber daya udang secara langsung (Tian et al., 2009; Zeng et al., 2018). Adapun selang kelas dan bobot aspek karakteristik habitat mengacu pada beberapa rujukan (Suwardi \& Rachim, 2008; Brower \& Zar, 1998; FAO, 1998; Dall et al., 1990). Selang kelas "sangat sesuai" diasumsikan bernilai sangat sesuai untuk habitat udang, "sesuai" bernilai cukup sesuai, dan "tidak sesuai" bernilai tidak sesuai (Price, 2016).

\section{HASIL DAN PEMBAHASAN}

\subsection{Karakteristik Perairan dan Sedimen di Teluk Ciletuh sebagai Habitat Udang Penaeid}

Habitat udang penaeid di Teluk Ciletuh dikaji berdasarkan aspek oseanografi dan sedimennya untuk melihat kesesuaian kedua aspek sebagai daerah penangkapan dan habitat udang penaeid. Table 2 menyajikan nilai dan karakteristik setiap parameter yang ditinjau berdasarkan aspek oseanografi. Tinggi gelombang di Teluk Ciletuh berkisar antara 1-1,25 m, atau diklasifikasikan sebagai gelombang laut tenang (slight sea), karena ketinggiannya $<1,25 \mathrm{~m}$. 
Kecepatan arus di permukaan perairan Teluk Ciletuh sebesar $0-5 \mathrm{~cm} / \mathrm{s}$. Kecepatan arus di kedalaman $10 \mathrm{~m}$ dari permukaan perairan antara $5-10 \mathrm{~cm} / \mathrm{s}$. Adapun arah arus permukaan dan kedalaman $10 \mathrm{~m}$ dari permukaan perairan di Teluk Ciletuh menunjukkan kesamaan, yaitu arus timur atau timur laut. Kecepatan arus di Teluk Ciletuh tergolong kedalam arus berkecepatan rendah atau perairan tenang. Arusnya berkecepatan rendah, karena lokasinya cukup terlindung. Trujillo \& Thurman (2011) menjelaskan bahwa perairan teluk merupakan perairan yang sedikit mendapat pengaruh gelombang dan arus, karena energinya telah terdeformasi dan lebih memengaruhi daerah tanjung (headland). Arusnya lebih banyak dipengaruhi oleh gelombang yang dibangkitkan oleh angin dan pasang surut. Massa air lebih banyak berpindah menuju ke dalam teluk. Perairan dengan arus yang tenang, menurut Dall et al. (1990), sangat disukai oleh udang, karena energi yang dibutuhkan untuk mempertahankan posisi dan bergerak lebih sedikit.

Tipe pasang surut di perairan Teluk Ciletuh diklasifikasikan sebagai pasang surut campuran harian ganda (Figure 2). Pasang dan surut terjadi dua kali per hari dengan tinggi dan periode yang berbeda (Stewart, 2008). Perairan sering mengalami proses sedimentasi dari pasang surut, sehingga Teluk Ciletuh banyak mendapatkan masukan sedimen dan nutrien secara berkala yang baik untuk kelangsungan hidup udang penaeid.

Suhu perairan Teluk Ciletuh berkisar antara $26-28^{\circ} \mathrm{C}$ untuk kedua permukaan perairan dan kedalaman $10 \mathrm{~m}$ dari permukaan perairannya. Hasilnya tidak berbeda dengan beberapa penelitian yang telah dilakukan sebelumnya. Menurut Badan Lingkungan Hidup Kabupaten Sukabumi (2003), suhu perairannya antara $28,1-28,6^{\circ} \mathrm{C}$. Suhu perairan Teluk Ciletuh termasuk perairan yang sesuai untuk habitat sumber daya udang. Hasil penelitian Hoang et al. (2002) membuktikan bahwa udang memiliki tingkat kelangsungan hidup (survival rate) yang lebih tinggi pada suhu perairan $27^{\circ} \mathrm{C}$ dibandingkan dengan suhu yang lebih rendah. Menurut Dall et al. (1990) dan Aziz \& Greenwood (1981), tingkat ke-langsungan hidup udang akan semakin menurun apabila suhu lebih tinggi.

\section{Table 2. Characteristics of Ciletuh Bay waters based on oceanography aspects.}

\begin{tabular}{|c|c|}
\hline $\begin{array}{c}\text { Parameter } \\
\text { Oceanographic }\end{array}$ & $\begin{array}{c}\text { Valuel } \\
\text { Characteristics }\end{array}$ \\
\hline Wave & $1-1.25 \mathrm{~m}$ \\
\hline Surface currents & $0-5 \mathrm{~cm} / \mathrm{s}$ \\
\hline $\begin{array}{l}\text { Currents at a depth of } \\
10 \mathrm{~m} \text { from sea level }\end{array}$ & $5-10 \mathrm{~cm} / \mathrm{s}$ \\
\hline Tidal & $\begin{array}{l}\text { Mixed tide } \\
\text { prevailing } \\
\text { semidiurnal }\end{array}$ \\
\hline Surface temperature & $26-28^{\circ} \mathrm{C}$ \\
\hline $\begin{array}{l}\text { Temperatures at a } \\
\text { depth of } 10 \mathrm{~m} \text { from sea } \\
\text { level }\end{array}$ & $26-28^{\circ} \mathrm{C}$ \\
\hline Surface salinity & $33-33.5 \%$ \\
\hline $\begin{array}{l}\text { Salinity at } 10 \mathrm{~m} \text { depth } \\
\text { from sea level }\end{array}$ & $33-33.5 \%$ \\
\hline
\end{tabular}

Source: Meteorology Climatology and Geophysics Council (2019).

Perairan Teluk Ciletuh memiliki salinitas antara 33-33,5\% dan berada pada kondisi normal. Lalli \& Parsons (1997) menjelaskan bahwa perairan pantai dengan kedalaman yang dangkal biasanya memiliki salinitas 27-30\%o.

Adapun Kemen. LH (2004) menetapkan bahwa salinitas yang berada pada rentang baku mutu air laut untuk biota laut berkisar 33-34\%o.

Sedimen permukaan dasar perairan Teluk Ciletuh mengandung $\geq 80 \%$ lanau dan $<12 \%$ lempung, atau tergolong sebagai sedimen lanau (silt) (Suwardi \& Rachim, 2008). Keberadaan dua sungai, yaitu Sungai Cimarinjung dan Sungai Ciletuh, yang bermuara di Teluk Ciletuh sangat 


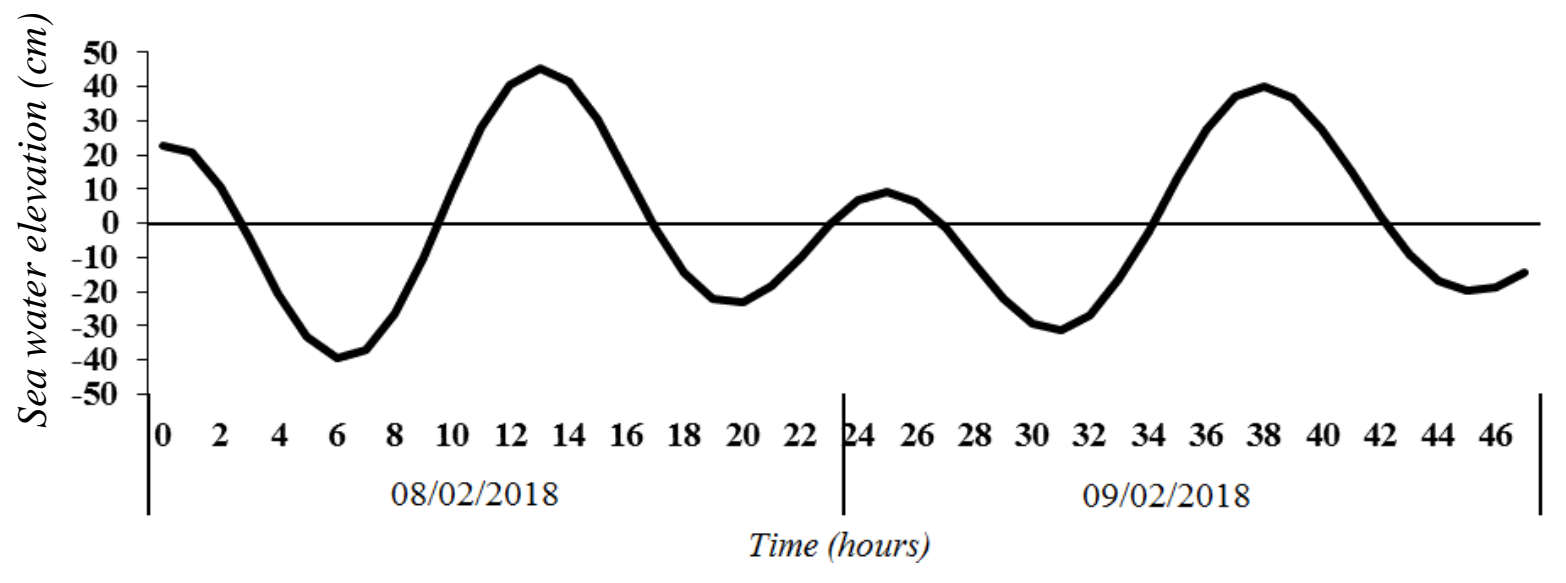

Figure 2. Sea level pattern from the tides in Ciletuh Bay waters (Marine Reseacrh Center, Ministry of Marine and Fisheries 2018).

berkontribusi dalam transportasi sedimen yang didominasi oleh lanau. Sedimen yang terbawa aliran sungai akan mengendap di permukaan dasar perairan. Hasil kajian Nittrouer et al. (2007) dan Veerasingam et al. (2014) menjelaskan bahwa landas kontinen yang dipengaruhi oleh masukan air sungai memiliki sedimen dominan dengan tekstur berukuran kecil, seperti lanau dan lempung.

\subsection{Jenis dan Kelimpahan Udang Penaeid}

Ada dua jenis udang penaeid yang tertangkap di Teluk Ciletuh, yaitu udang dogol (M. ensis) dan udang jerbung ( $F$. merguiensis). Udang dogol tertangkap lebih banyak dan berat dibandingkan dengan udang jerbung. Udang dogol tertangkap sebanyak 514 individu dengan berat $2103 \mathrm{~g}$, atau lebih tinggi dibandingkan dengan udang jerbung (305 individu; 1692 g) (Figure 3; Figure 4).

Udang dogol dan jerbung dapat tertangkap dikarenakan perairan Teluk Ciletuh merupakan satu wilayah distribusi jenisnya. FAO (1998) menginformasikan bahwa distribusi udang dogol dan jerbung meliputi perairan Indonesia dan seluruh perairan pantai Samudera Pasifik bagian barat. Pengoperasian alat sampling yang dilakukan di perairan pada kedalaman 5-10 $m$ dengan substrat permukaan dasar perairan

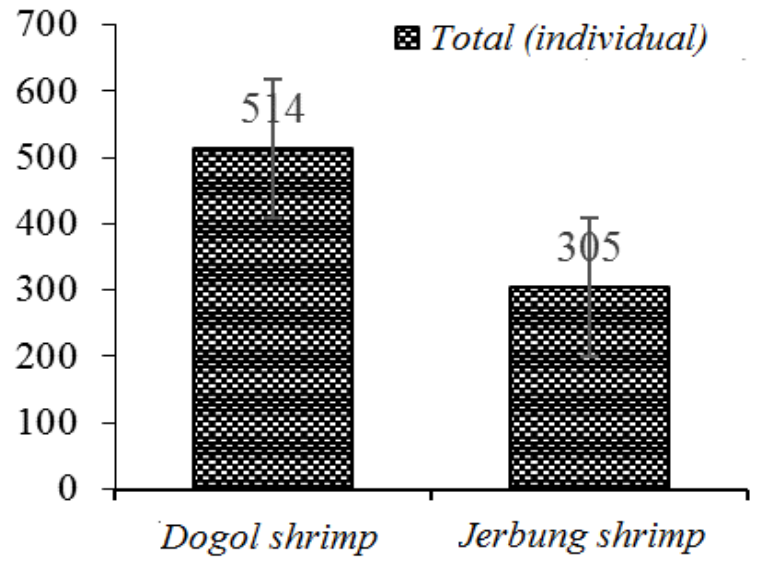

Figure 3. Number of penaeid shrimps per species.

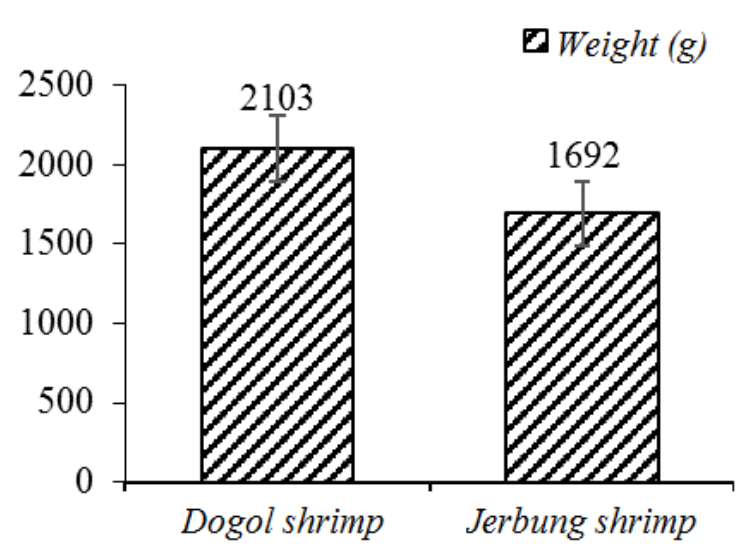

Figure 4. Weight of penaeid shrimps per species.

berlumpur merupakan habitat kedua jenis udang. Zarshenas et al. (2014) dan Samphan 
et al. (2016) menjelaskan kedua jenis udang tersebut menyukai perairan dengan kedalaman 8-95 m.

\subsection{Kesesuaian Kawasan}

\subsubsection{Kesesuaian Kawasan Berdasarkan Potensi Sumber Daya Udang Penaeid}

Sebaran berat hasil tangkapan dan kepadatan udang penaeid di perairan Teluk Ciletuh disajikan secara spasial (Figure 5). Berdasarkan tingkat kesesuaian parameter berat hasil tangkapan, perairan yang termasuk kategori $\mathrm{S} 1$ seluas 68,576 ha atau $14,3 \%$ dari luas total kawasan kajian (479,288 ha). Setiap satu sapuan pukat tarik yang dilakukan di perairannya berpotensi menghasilkan berat hasil tangkapan antara 0,41-0,6 kg. Selanjutnya, perairan yang dikategorikan S2 seluas 217,931 ha $(45,5 \%)$ dengan potensinya mencapai 0,21-0,4 $\mathrm{kg} /$ sapuan. Perairan dengan kategori N luasnya 192,781 ha $(40,2 \%)$ dengan potensi yang dapat dicapai $0-0,2 \mathrm{~kg} / \mathrm{sapuan}$.

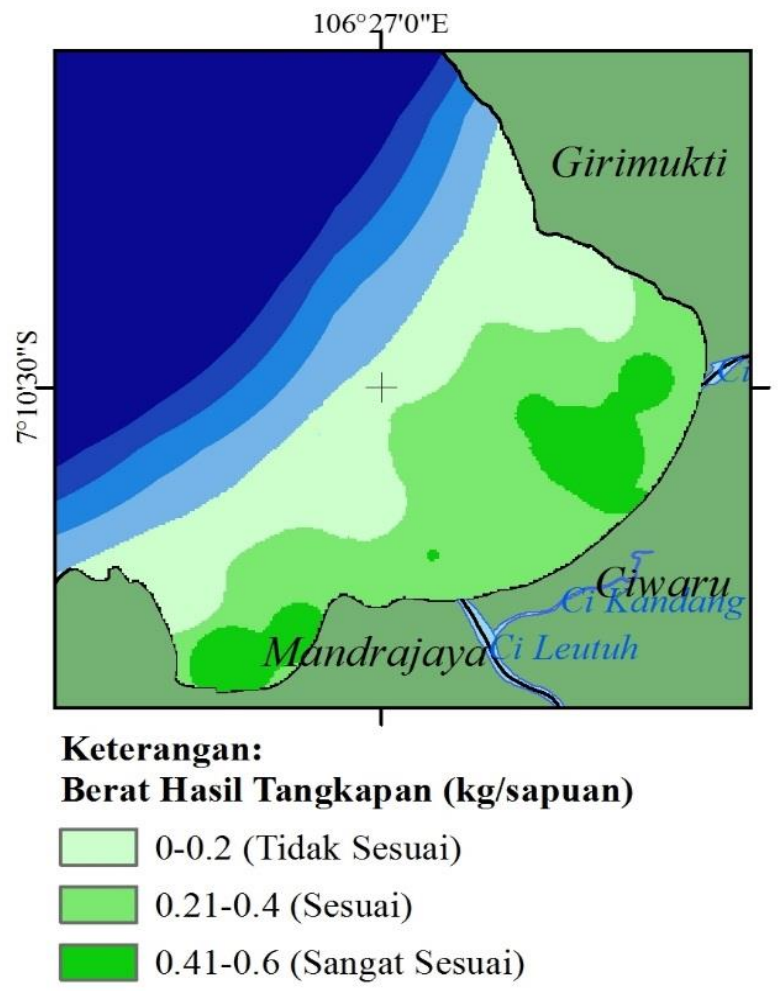

Potensi pemanfaatan sumber daya udang penaeid dijelaskan lebih lanjut secara spasial berdasarkan parameter kepadatan. Perairan yang termasuk kategori S1 seluas 23,449 ha atau hanya $4,9 \%$ dari total luas kawasan kajian. Setiap satu hektar perairannya berpotensi menghasilkan kepadatan seberat 1,6-2,25 kg. Perairan yang dikategorikan S2 seluas 240,494 ha (50,2\%). Potensi pemanfaatannya mencapai $0,76-1,5$ $\mathrm{kg} / \mathrm{ha}$. Adapun perairan yang dikategorikan $\mathrm{N}$ seluas 215,345 ha $(44,9 \%)$ dengan potensi pemanfaatan yang hanya mencapai $0-0,75$ $\mathrm{kg} / \mathrm{ha}$.

Sebaran spasial berat hasil tangkapan dan kepadatan yang memiliki nilai kesesuaian tertinggi (S1) secara dominan berada di perairan yang tidak jauh dari mulut sungai di Desa Ciwaru. Selain itu, distribusinya juga tinggi di perairan pantai Desa Mandrajaya. Sebaran yang dikategorikan S2 tersebar luas di perairan dekat mulut sungai maupun ke arah perairan yang berjarak \pm 500 $\mathrm{m}$ dari garis pantai. Adapun perairan dengan
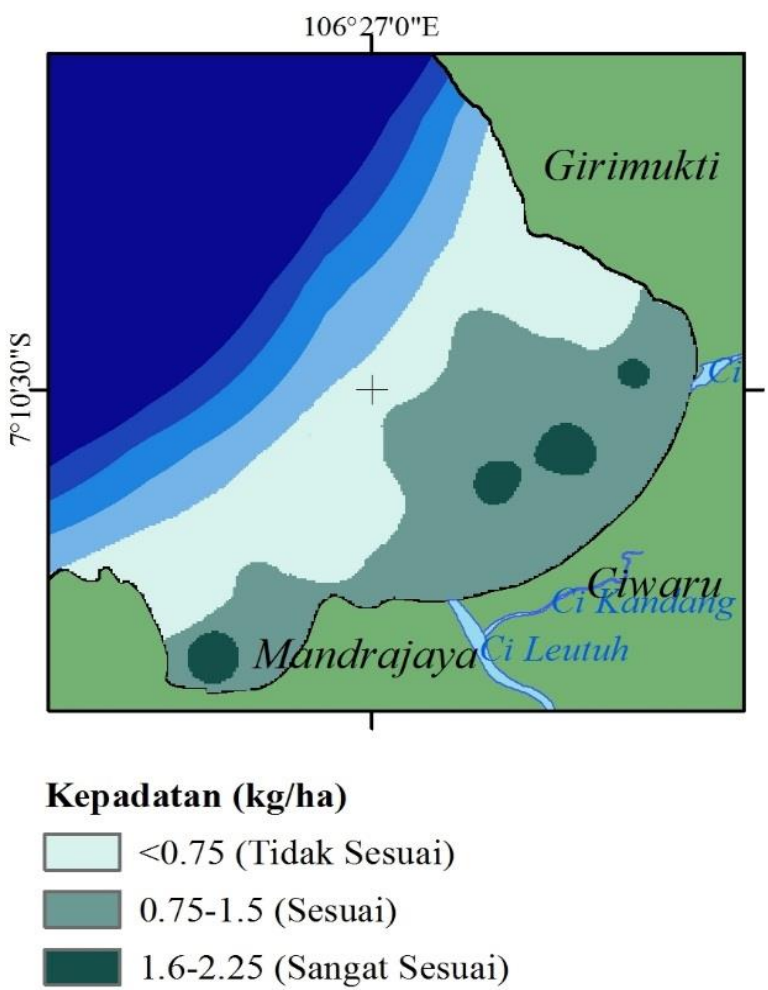

Figure 5. Spatial distribution of catch and biomass parameters of penaeid shrimp in Ciletuh Bay waters. 
nilai kesesuaian terendah $(\mathrm{N})$ mendominasi perairan dengan jarak sekitar $800 \mathrm{~m}$ atau lebih dari garis pantai. Perairan tersebut dijelaskan berdasarkan pengaruh masukan air sungai dan aliran air (run-off) dari daratan. Trigos et al. (2014) menjelaskan bahwa air sungai dan run-off cenderung membawa bahan organik berupa detritus ke perairan. Kedua komponen terakumulasi di sekitar mulut sungai atau permukaan dasar perairan dekat pantai dan kemudian dimanfaatkan oleh hewan pemakan detritus (detrisus feeder), seperti udang-udangan (Gray \& Ellitot, 2009; Xiao \& Liu, 2010; Schmidt et al., 2010). Khusus distribusi berat hasil tangkapan dan kepadatan yang tinggi di perairan pantai Desa Mandrajaya, kondisinya dipengaruhi keberadaan tambak udang di daratan pesisirnya. Slamet et al. (2001) menyatakan bahwa jumlah organisme pengurai (scavenger) mengalami peningkatan di perairan yang mendapat masukan bahan organik dari buangan air tambak udang.

\subsubsection{Kesesuaian Kawasan Berdasarkan Fraksi Sedimen}

Sebaran spasial sedimen fraksi sand, silt, dan clay di perairan Teluk Ciletuh disajikan secara spasial (Figure 6).
Berdasarkan hasil analisis fraksi sand, perairan yang termasuk kategori S1 untuk habitat udang penaeid seluas 302,865 ha atau $63 \%$ dari total luas kawasan kajian. Sedimen di perairannya memiliki persentase fraksi sand sekitar $0-1 \%$. Perairan dengan kategori S2 seluas 93,354 ha $(19,5 \%)$ dengan persentase fraksi sand sekitar 1,1-2\%. Adapun perairan yang dikategorikan $\mathrm{N}$ atau dengan persentase fraksi sand $2,1-4 \%$ seluas 83,069 ha $(17,3 \%)$.

Hasil analisis sedimen fraksi silt dan clay di seluruh titik sampling menunjukkan jumlah persentase yang seragam. Seluruh titik sampling menghasilkan persentase fraksi silt $\geq 80 \%$ dan clay $<10 \%$. Hasilnya menunjukkan bahwa seluruh kawasan kajian $(479,288$ ha atau $100 \%)$ dikategorikan sebagai kawasan yang sangat sesuai (S1) untuk habitat udang penaeid dan kawasan pemanfaatan.

Dominasi fraksi silt dan clay di Teluk Ciletuh menjadikan perairannya sebagai habitat dan kawasan pemanfaatan udang penaeid yang ideal berdasarkan karakteristik sedimennya. Branford (1981) menjelaskan bahwa udang penaeid sangat menyukai sedimen yang sangat halus, seperti lanau. Freire et al. (2008) menambahkan bahwa
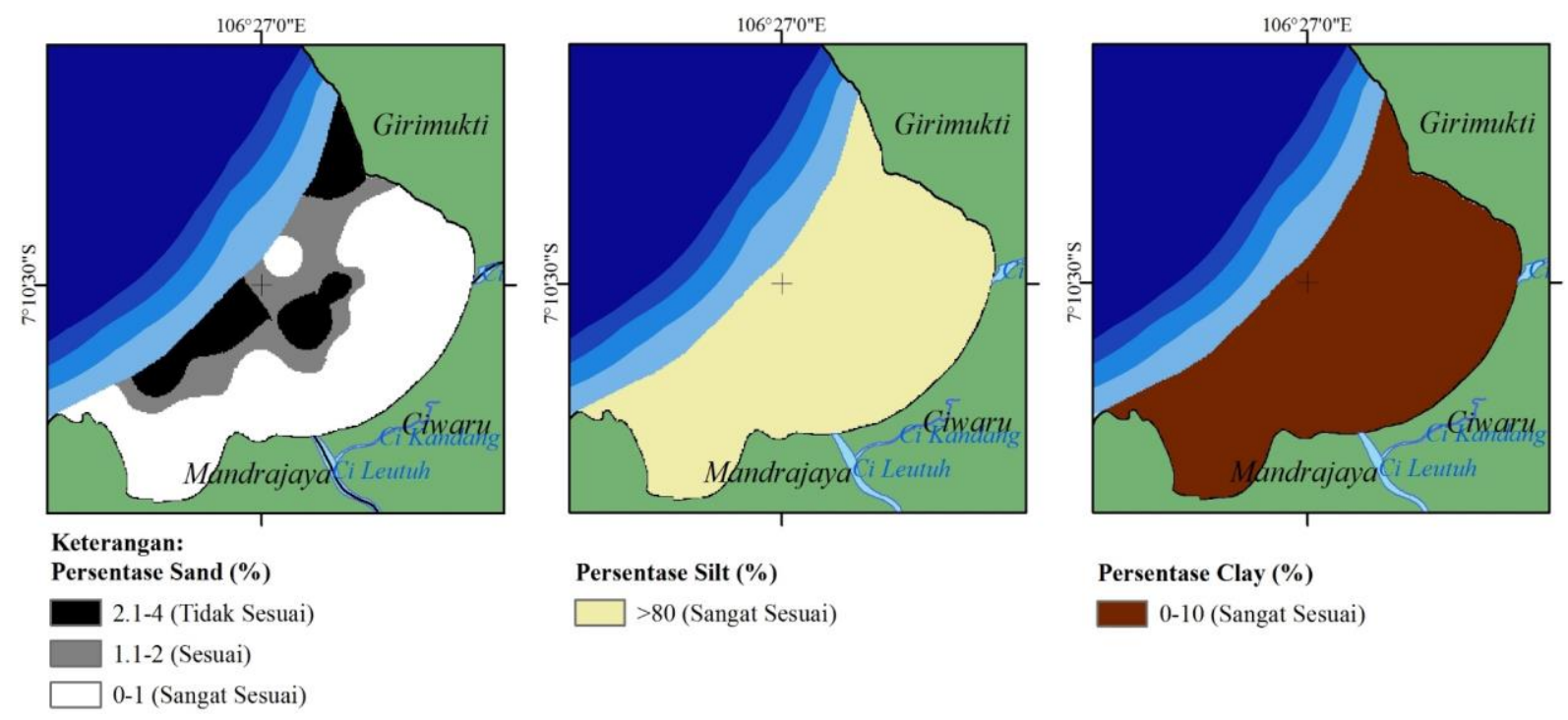

Figure 6. Spatial distribution of sand, silt and clay fraction in Ciletuh Bay waters. 
sedimen dengan tingkat kehalusan yang tinggi memudahkan udang untuk mengubur diri sebagai bagian dari kebiasaan berlindung dari mangsa dan beristirahat. Selain itu, sedimen yang dikategorikan lanau cocok untuk kegiatan penangkapan yang menyapu permukaan dasar perairan. Alasannya karena alat tangkap yang dioperasikan di permukaan dasar perairan yang halus menghasilkan fraksi yang kecil, sehingga alat tangkap lebih mudah untuk ditarik (Puspito et al., 1997).

\subsubsection{Kesesuaian Kawasan Pemanfaatan Sumber Daya Udang Penaeid}

Lima raster dari lima parameter kesesuaian menghasilkan satu raster akhir yang menunjukkan kawasan pemanfaatan sumber daya udang penaeid yang sesuai (Figure 7). Berdasarkan perhitungan luasnya, perairan yang dikategorikan S1 209,254 ha atau $43,7 \%$ dari total luas kawasan kajian. Perairan yang dikategorikan S2 seluas
209,067 ha $(43,6 \%)$ dan yang tidak sesuai (N) seluas 60,967 ha $(12,7 \%)$.

Potensi perairan yang telah dikategori-kan ke dalam tingkat kesesuaian kawasan ditentukan berdasarkan rumus pendugaan biomassa yang hasilnya disajikan pada Table 3. Rata-rata berat hasil tangkapan di perairan dengan kategori S1 mencapai $0,417 \quad \mathrm{~kg}$ per sapuan. Kepadatannya mencapai $1,18 \mathrm{~kg} / \mathrm{ha}$, sedangkan biomassanya mencapai $247,82 \mathrm{~kg}$. Perairan dengan kategori S2 menghasilkan rata-rata berat hasil tangkapan $0,103 \mathrm{~kg}$ per sapuan. Kepadatan dan biomassa masingmasing mencapai $0,39 \mathrm{~kg} / \mathrm{ha}$ dan $81,23 \mathrm{~kg}$. Perairan dengan kategori $\mathrm{N}$ menghasilkan rata-rata berat hasil tangkapan $0,003 \mathrm{~kg}$ per sapuan. Nilainya yang kecil membuat nilai kepadatan dan biomassanya juga kecil dengan masing-masing bernilai $0,001 \mathrm{~kg} / \mathrm{ha}$ dan $0,72 \mathrm{~kg}$.

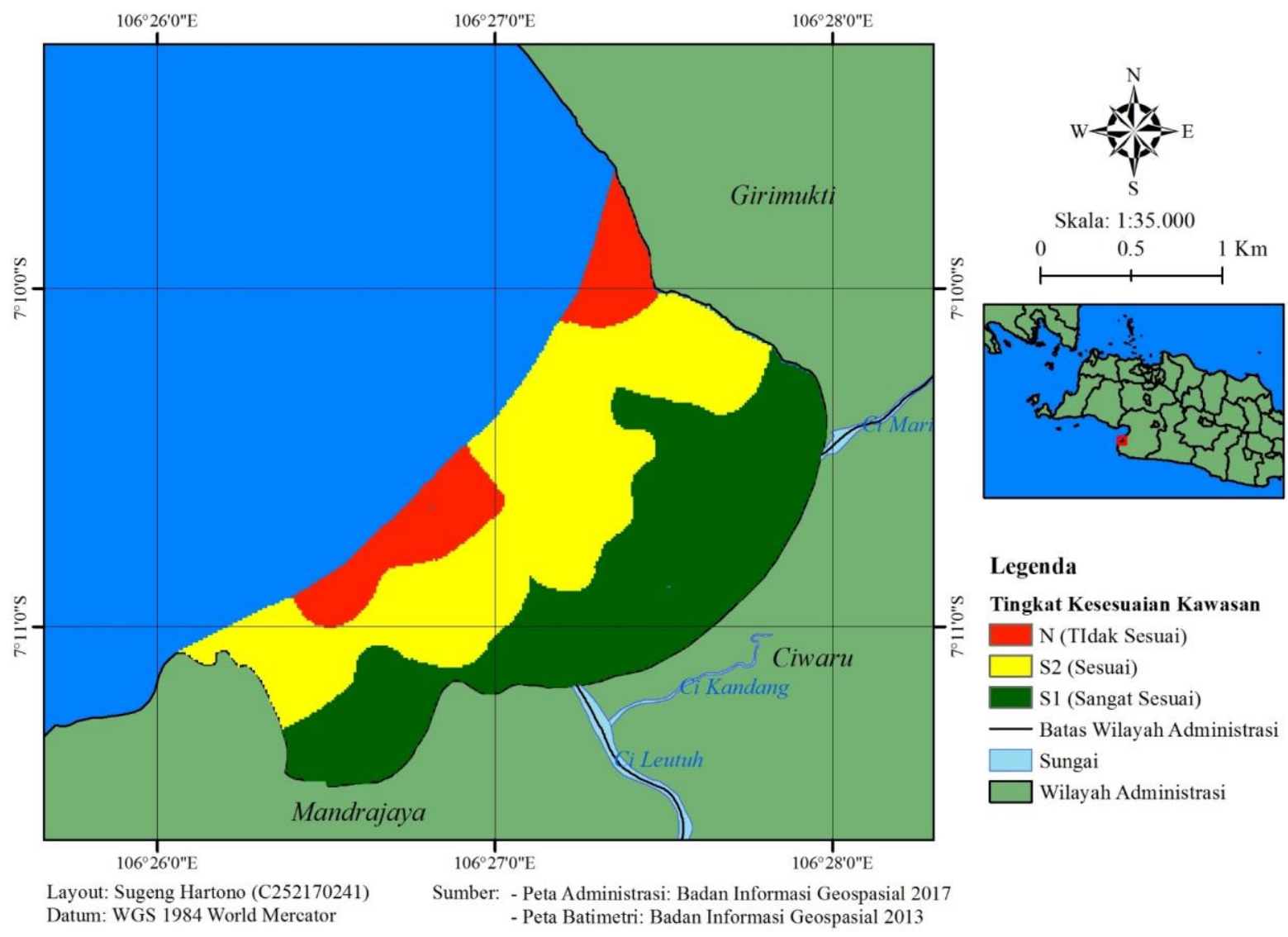

Figure 7. Areas of penaeid shrimp resources utilization based on suitability level. 
Table 3. The potential of penaeid shrimp resources in Ciletuh Bay waters based on the level of area suitability.

\begin{tabular}{ccccc}
\hline $\begin{array}{c}\text { Waters per } \\
\text { category }\end{array}$ & $\begin{array}{c}\text { Average catch weight } \\
\text { per sweep }(\mathrm{kg})\end{array}$ & $\begin{array}{c}\text { Average sweep } \\
\text { area }(\mathrm{ha})\end{array}$ & $\begin{array}{c}\text { Density } \\
(\mathrm{kg} / \mathrm{ha})\end{array}$ & $\begin{array}{c}\text { Estimated } \\
\text { biomass }(\mathrm{kg})\end{array}$ \\
\hline S1 & 0.417 & 0.352 & 1.18 & 247.82 \\
S2 & 0.103 & 0.265 & 0.39 & 81.23 \\
$\mathrm{~N}$ & 0.003 & 0.252 & 0.01 & 0.72 \\
\hline
\end{tabular}

Tingkat kesesuaian kawasan semakin meningkat apabila jaraknya semakin ke arah pantai. Kawasan pemanfaatan yang memiliki nilai kesesuaian tertinggi (S1) secara dominan berada di perairan yang berjarak sekitar 0-500 m dari garis pantai. Sebarannya yang dikategorikan sesuai (S2) lebih tersebar di perairan dengan jarak $\pm 500-750 \mathrm{~m}$. Adapun perairan dengan nilai kesesuaian terendah $(\mathrm{N})$ mendominasi perairan dengan jarak sekitar $800 \mathrm{~m}$ atau lebih dari garis pantai. Perairan tersebut menunjukkan bahwa kelimpahan sumber daya udang penaeid semakin tinggi dan habitatnya semakin sesuai seiring jarak perairannya mendekati pantai.

Hasil penentuan kawasan dapat dijadikan panduan dalam memanfaatkan dan mengelola sumber daya udang penaeid. Berdasarkan hasilnya. nelayan dapat melakukan kegiatan penangkapan di perairan Teluk Ciletuh yang dikategorikan sangat sesuai (S1) dan sesuai (S2). Kawasan perairannya dimulai dari garis pantai hingga $\pm 750 \mathrm{~m}$ ke arah laut lepas dengan kedalaman 5-10 m. Adapun suhunya berkisar antara 26$28^{\circ} \mathrm{C}$ dan salinitas 33-33,5\% . Selain itu. pengelola perikanan juga dapat memfokuskan pengelolaan kegiatan perikanan di kawasan perairan yang sama.

Pengelolaan yang dapat direkomendasikan kepada pengelola adalah pengawasan status sumber daya perikanan udang penaeid berdasarkan kawasan. Pengawasannya dilakukan berdasarkan tiga aspek yang meliputi lingkungan, biologi, dan kegiatan perikanan. Berdasarkan aspek lingkungan, pengelola melakukan pengawasan kondisi habitat sumber daya udang penaeid di kawasan yang telah dirancang sebagai kawasan pemanfaatan. Pendataan parameter lingkungan perlu dilakukan secara berkala, seperti parameter oseanografi, kualitas air, atau kualitas habitat bentik. sehingga kondisi lingkungannya dapat terkontrol dan kerusakannya dapat dicegah akibat kegiatan perikanan. Kemudian pengawasan berdasarkan aspek biologi dimaksudkan untuk memonitor keberadaan dan kelimpahan sumber daya udang penaeid dan sumber daya perikanan lainnya di kawasan pemanfaatan. Eksistensi dan kelimpahan dijadikan indikator untuk mengkaji keseimbangan antar populasi sumber daya perairan di dalam ekosistemnya. Adapun pengawasan berdasarkan aspek kegiatan perikanan bertujuan untuk mengkaji performa dan dampak kegiatan perikanan.

Pendataan berbagai komponen kegiatan perikanan seperti komposisi dan jumlah hasil tangkapan, upaya penangkapan, titik koordinat penangkapan, dan pendapatan harus dilakukan secara berkala. Tujuannya untuk menentukan tingkat pemanfaatan dan alokasi yang tepat di kawasan pemanfaatan yang telah ditentukan. Dengan demikian, kegiatan perikanan dapat berjalan sesuai dengan daya dukung sumber dayanya (Garcia et al., 2003; Cochrane \& Garcia, 2009; Cuenpagdee, 2011; Maeden \& Manjarrez, 2013).

\section{KESIMPULAN}

Perairan Teluk Ciletuh merupakan wilayah yang "sesuai" sebagai daerah penangkapan dan habitat udang penaeid. Berdasarkan karakteristik habitatnya. 
sedimen permukaan dasar perairan Teluk Ciletuh dikategorikan sebagai lanau (silt). Terdapat dua jenis udang penaeid yang tertangkap di perairan ini. yaitu udang dogol (M. ensis) dan udang jerbung ( $F$. merguiensis). Perairannya memiliki suhu berkisar antara $26-28^{\circ} \mathrm{C}$ dan salinitas 33$33,5 \%$ pada kedalaman 5-10 m. Perairan yang dikategorikan S1 untuk kegiatan pemanfaatan seluas 209,254 ha atau $43,7 \%$ dari luas total kawasan kajian (479,288 ha). Adapun perairan yang dikategorikan S2 seluas 209,067 ha $(43,6 \%)$ dan yang dikategorikan $\mathrm{N}$ seluas 60,967 ha $(12,7 \%)$. Dugaan total biomassanya mencapai 247,82 kg untuk perairan dengan kategori S1, 81,23 $\mathrm{kg}(\mathrm{S} 2)$, dan 0,72 kg (N).

\section{UCAPAN TERIMA KASIH}

Peneliti mengucapkan terima kasih kepada seluruh pihak dari Dinas Kelautan dan Perikanan Kabupaten Sukabumi dan PPI Ciwaru yang telah membantu dalam penyediaan data dan informasi yang berguna untuk penelitian.

\section{DAFTAR PUSTAKA}

Achilleos, G.A. 2011. The Inverse Distance Weighted interpolation method and error propagation mechanismcreating a DEM from an analogue topographical map. J. of Spatial Science, 56(2): 283-304. https://doi.org/10.1080/14498596.201 1.623348

Aziz, K.A. \& J.G. Greenwood. 1981. A laboratory investigation of temperature and salinity tolerances of juvenile Metapenaeus bennettae Racek and Dall (Crustacea: Penaeidae). J. of Experimental Marine Biology and Ecology, 54(2): 137-147.

https://doi.org/10.1016/0022-

0981(81)90140-4
Badan Lingkungan Hidup Kabupaten Sukabumi. 2003. Profil pencemaran sungai di Teluk Palabuhanratu Kabupaten Sukabumi: laporan akhir. Pemerintah Kabupaten Sukabumi. Indonesia. $70 \mathrm{p}$.

Balai Penelitian Perikanan Laut. 2014. Potensi lestari dan tingkat pemanfaatan sumber daya ikan di Wilayah Pengelolaan Perikanan Republik Indonesia (WPP-RI). Ref Graphika. Jakarta. 224 p.

Blomqvist, S. 1991. Quantitative sampling of soft-bottom sediments: problems and solutions. Mar. Ecol. Prog. Ser., 72: 295-304. https://doi.org/10.3354/meps072295

Bolliger, J., A. Bergamini, S. Stofer, F. Kienast, \& C. Scheidegger. 2007. Predicting the potential spatial distributions of epiphytic lichen species at the landscape scale. The Lichenologist, 39(3): 279-291. https://doi.org/10.1017/S0024282907 006652

Brower, J.E. \& J.H. Zar. 1998. Field and laboratory methods for general ecology. WMC Brown Publishers. Iowa. $273 \mathrm{p}$.

Badan Meteorologi Klimatologi Geofisika. 2019. Ocean forecast system. BMKGOFS. http://peta-maritim.bmkg.go.id/ ofs-static [diunduh 2019 Feb 15].

Branford, J.R. 1981. Sediment and the distribution of penaeid shrimp in the Sudanese Red Sea. Estuarine Coastal Shelf Sci., 13: 349-354. https://doi.org/10.1016/S03023524(81)80032-1

Cochrane, K.L. \& S.M. Garcia. 2009. A fishery manager's guidebook. second edition. The Food and Agriculture Organization of the United Nations dan Wiley-Blackwell. Roma. 535 p.

Cuenpagdee, R. 2011. World Small-Scale Fisheries: Contemporary Visions. Eburon Academic Publishers. Belanda. 400 p. 
Dall, W., B.J. Hill, P.C. Rothlisberg, \& D.J. Sharples. 1990. Advances in marine biology volume 27: the biology of the Penaeidae. Academic Press Limited. London. 498 p.

Eleftheriou, A. 2013. Methods for the study of marine benthos. Wiley-Blackwell. Chicester. $494 \mathrm{p}$. https://doi.org/10.1002/97811185423 92

Food and Agriculture Organization (FAO). 1998. FAO species identification guide for fishery purposes. the living marine resources of the Western Central Pacific. volume 2. cephalopods. crustaceans. holothurians. and sharks. FAO. Roma. 687-1396 pp.

Freire, F.A., A.C. Luchiari, \& V. Fransozo. 2008. Environmental substrate selection and daily habitual activity in Xiphopenaeus kroyeri shrimp (Heller. 1862) (Crustacean: Penaeioidea). Indian J. of Geo-Marine Sci., 40(3): 325-330.

Garcia, S.M., A. Zerbi, C. Aliaume, T.D. Chi, \& G. Lasserre. 2003. The ecosystem approach to fisheries. issues. terminology. principles. institutional foundations. implementation. and outlook. FAO. Roma. $71 \mathrm{p}$.

Goineau, A., C. Fontaniera, F.J. Jorissena, B. Lansard, R. Buscail, A. Mourete, P. Kerhervé, S. Zaragosi, E. Ernoultab, C. Artéro, P. Anschutz, E. Metzgera, \& C. Rabouillef. 2011. Live (stained) benthic foraminifera from the Rhône prodelta (Gulf of Lion. NW Mediterranean): Environmental controls on a riverdominated shelf. J. of Sea Research, 65(1): 58-75.

https://doi.org/10.1016/j.seares.2010. 07.007

Guisan, A. \& W. Thuiller. 2005. Predicting species distribution: offering more than simple habitat models. Ecol. Lett., 8(9): 993-1009. https://doi.org/10.1111/j.14610248.2005.00792.x

Gray, J.S. \& M. Elliot. 2009. Ecology of marine sediments. Oxford University Press. Oxford. 250 p.

Hart, C., F.G. Troyl, \& D.T. Matthew. 2018. Utilisation of a recovering wetland by a commercially important species of penaeid shrimp. Wetlands. Ecol Manage., 26: 665-675. https://doi.org/10.1007/s11273-0189599-6

Hufiadi. 2008. Proporsi dan komposisi hasil tangkapan jaring tiga lapis (Trammel Net) di Palabuhanratu. Bawal, 2(2): 69-74. http://doi.org/10.15578/bawal.2.2.200 8.69-74

Hoang, T., S.Y. Lee, C.P. Keenan, \& G.E. Marsden. 2002. Effect of temperature on spawning of Penaeus merguiensis. J. of Thermal Biology, 27: 433-437. https://doi.org/10.1016/S03064565(02)00013-X

Lalli, C.M. \& T.R. Parsons. 1997. Biological oceanography: an introduction. second edition. Elsevier ButterworthHeinemann. Inggris. 337 p.

Loneragan, N.R., R.A. Kenyon, M.D. Haywood, \& D.J. Staples. 1994. Population dynamics of juvenile tiger prawns (Penaeus esculentus and $P$. semisulcatus) in seagrass habitats of the western Gulf of Carpentaria. Australia. Marine Biology, 119:133143. https://doi.org/10.1007/BF00350115

Maeden, G.J. \& J.A. Manjarrez. 2013. Advances in geographic information systems and remote sensing for fisheries and aquaculture. FAO. Roma. 452 p.

Marasabessy, I., A. Fahrudin, Z. Imran, \& S.B. Agus. 2018. Strategi pengelolaan berkelanjutan pesisir dan laut Pulau Nusa Manu dan Pulau Nusa Leun di 
Kabupaten Maluku Tengah. J. of Regional and Rural Development Planning, 2(1) :1-22. https://doi.org/10.29244/jp2wd.2018. 2.1.11-22

Marini, M., A. Suman, A. Farajallah, \& Y. Wardiatno. 2017. Identifying Penaeus merguiensis de Man. 1888 stocks in Indonesian Fisheries Management Area 573: a truss network analysis approach. AACL Bioflux, 10(4): 922935.

Mehanna, S.F., J. Al-Mamary, \& L. AlKharusi. 2012. Fishery characteristics and population dynamics of indian white shrimp Fenneropenaeus indicus from Arabian Sea. Sultanate of Oman. Turkish J. of Fisheries and Aquatic Sciences, 12: 1-8.

http://www.trjfas.org/abstract.php?lan $\mathrm{g}=\mathrm{en} \& \mathrm{id}=498$

Mendenhall, W., R.J. Beaver, \& B.M. Beaver. 2013. Introduction to probability and statistics. Brooks/ Cole. Boston. 752 p.

Morris, L. \& D. Ball. 2006. Habitat suitability modelling of economically important fish species with commercial fisheries data. $J$. of Marine Science, 63: 1590-1603. https://doi.org/10.1016/j.icesjms.2006 .06 .008

Nittrouer, C.A., J.A. Austin, M.E. Field, J.H. Kravitz, J.P Syvitski, \& P.L. Wiberg. 2007. Continental margin sedimentation: from sediment transport to sequence stratigraphy. Blackwell Publishing. Inggris. $560 \mathrm{p}$.

Price, M. 2016. Mastering ArcGIS. Mc Graw Hill. New York. 624 p.

Puspito, G., K. Yamamoto, T. Hiraishi, \& K. Nashimoto. 1997. Lower line shape and tension of shrimp trammel net towed along the hypotenuse of right triangle. Fisheries Science, 63(1): 15. https://doi.org/10.2331/fishsci.63.1

Samphan, P., H. Sukree, \& T. Reunchai. 2016. Population dynamics of the greasyback shrimp (Metapenaeus ensis. De Haan. 1844) in the Songkhla Lake. Songkhla Province. Thailand. J. of Agricultural Technology, 12(1): 75-89.

Schmidt, F., K.U. Hinrichs, \& M. Elvert. 2010. Sources. transport. and partitioning of organic matter at a highly dynamic continental margin. Marine Chemistry, 118(2): 37-55. https://doi.org/10.1016/j.marchem.20 09.10 .003

Slamet, B., I.W. Arthana, \& I.W. Suyasa. 2001. Studi kualitas lingkungan perairan di daerah budidaya perikanan laut di Teluk Kaping dan Teluk Pegametan. Bali. Ecotrophic, 3(1): 16-20.

https://ojs.unud.ac.id/index.php/ECO TROPHIC/article/view/2481

Spalding, M.D., H.E. Fox, G.R. Allen, N. Davidson, Z.A. Ferdaña, M. Finlayson, B.S. Halpern, M.A. Jorge, A. Lombana, S.A. Lourie, K.D. Martin, E. McManus, J. Molnar, C.A. Recchia, \& J. Robertson. 2007. Marine ecoregions of the world: a bioregionalization of coastal and shelf areas. Bioscience, 57(7): 573-583. https://doi.org/10.1641/B570707

Sparre, P. \& S.C. Venema. 1998. Introduction to tropical fish stock assessment. part 1. manual. FAO. Roma. 407 p.

Stewart, R.H. 2008. Introduction to physical oceanography. Texas A \& $M$ University. Amerika. $354 \mathrm{p}$.

Store, R. \& J. Jokimäki. 2003. A GIS-based multi-scale approach to habitat suitability modeling. Ecological Modelling, 169: 1-15. https://doi.org/10.1016/S03043800(03)00203-5

Suwardi \& D.A Rachim. 2008. Morfologi dan klasifikasi tanah. Departemen Ilmu Tanah dan Sumberdaya Lahan IPB. Bogor. 294 p. 
Swaleh, K., B.K. Arara, R. Ruwa, \& P. Raburu. 2015. Ecosystem-based assessment of a prawn fishery in coastal Kenya using ecological indicators. Ecological Indicators. 50: 233-241.

https://doi.org/10.1016/j.ecolind.2014 .11 .013

Tian. S., X. Chen, Y. Chen, L. Xu, \& X. Dai. 2009. Evaluating habitat suitability indices derived from CPUE and fishing effort data for Ommatrephes bratramii in the northwestern Pacific Ocean. Fisheries Research, 95: 181188.

https://doi.org/10.1016/j.fishres.2008. 08.012

Trigos, S., J.R. García, N. Vicente, J. Tena, \& J. Torres. 2014. Utilization of muddy detritus as organic matter source by the fan mussel Pinna nobilis. Mediterranean Marine Science, 15(3): 667-674. http://doi.org/10.12681/mms.836

Trujillo, A.P. \& H. Thurman. 2011. Essentials of Oceanography 10th Edition. Prentice Hall. Amerika. 576 p.

Veerasingam, S., R. Venkatachalapathy, \& T. Ramkumar. Distribution of clay minerals in marine sediments off Chennai. Bay of Bengal. India: Indicators of sediment sources and transport processes. International $J$. of Sediment Research, 29(1): 11-23.
https://doi.org/10.1016/S1001-

6279(14)60018-4

Xiao, H.Y. \& C.Q. Liu. 2010. Identifying organic matter provenance in sediments using isotopic ratios in an urban river. Geochemical J., 44(3): 181-187. https://doi.org/10.2343/geochemj.1.00 59

Yulianda, F. 2019. Ekowisata perairan: suatu konsep kesesuaian dan daya dukung wisata bahari dan wisata air tawar. IPB Press. Bogor. 94 p.

Zarshenas, G.A., N. Niamaimandi, \& K. Pazir. 2014. Study on banana prawn (Fenneropenaeus merguiensis) movement in the Hormozgan waters in the northern Persian Gulf. Iranian Scientific Fisheries J., 22(4): 34-40. http://aquaticcommons.org/id/eprint/2 1976

Zeng, X., K. Tanaka, Y. Chen, K. Wanga, \& S. Zhanga. 2018. Gillnet data enhance performance of rockfishes habitat suitability index model derived from bottom-trawl survey data: A case study with Sebasticus marmoratus. Fisheries Research, 204: 189-196. https://doi.org/10.1016/j.fishres.2018. 02.009

Received :09 October 2019

Reviewed : 05 November 2019

Accepted : 10 April 2020 
